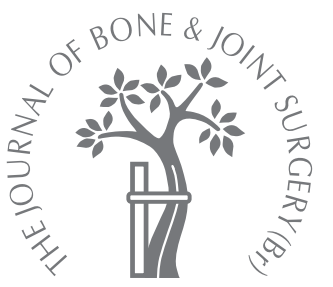

\title{
Treatment of checkrein deformity of the hallux
}

H. S. Lee, J. S. Kim, S.-S. Park, D.-H. Lee, J. M. Park, K. L. Wapner

From Asan Medical Center, Seoul, Korea

H. S. Lee, MD, Associate Professor

J. S. Kim, MD, Assistant Professor

I.-S. Park, MD, Associate Professor

D.-H. Lee, MD, Assistant Professor

J. M. Park, MD, Resident Department of Orthopedic Surgery

Asan Medical Center,

University of Ulsan College of Medicine, 388-1 Pungnap2dong, Songpa-gu, Seoul 138-736, Korea.

= K. L. Wapner, MD, Clinical Professor

Department of Orthopedic Surgery

University of Pennsylvania, 230 West Washington Square, Philadelphia, Pennsylvania 19106, USA.

Correspondence should be sent to Professor J. S. Kim; e-mail: micro@amc.seoul.kr

(C)2008 British Editorial Society of Bone and Joint Surgery doi:10.1302/0301-620X.90B8. $20563 \$ 2.00$

$J$ Bone Joint Surg $[\mathrm{Br}]$ 2008;90-B:1055-8.

Received 4 December 2007;

Accepted after revision 16 April

2008

\begin{abstract}
We studied 11 patients with checkrein deformities of the hallux who underwent surgical treatment. Six had lengthening of the flexor hallucis longus tendon by Z-plasty in the midfoot, and five underwent release of adhesions and lengthening of the tendon by Z-plasty at the musculotendinous junction at the fracture site.

All six patients who underwent Z-plasty at the midfoot showed complete correction of the deformity without recurrence. Of the five who had release of adhesions and Z-plasty of the tendon at the fracture site, two showed partial and one showed complete recurrence.
\end{abstract}

The checkrein deformity describes tethering of the flexor hallucis longus (FHL) tendon after fracture of the lower limb and is seen as a dynamic flexion deformity of the hallux. When the ankle is passively dorsiflexed, the flexion deformity becomes more prominent, but on passive plantar flexion the deformity is corrected completely.

It has been suggested that the deformity is the result of entrapment of the FHL in scar tissue or callus at the fracture site, ${ }^{1}$ but others feel that it results from contracture of the muscles after a subclinical compartment syndrome. ${ }^{2}$

Surgical treatment of the checkrein deformity has included simple release of adhesions at the fracture site, ${ }^{3-6}$ lengthening of the tendon of FHL at the fracture site by Z-plasty with release of adhesions ${ }^{2}$ and Z-plasty of the tendon at the midfoot without release of adhesions. $^{7}$

We have assessed this deformity in 11 patients in terms of the aetiology, the clinical and anatomical findings, the methods of treatment, the results following operation and recurrence.

\section{Patients and Methods}

We treated 11 patients with a checkrein deformity who underwent surgery between 2002 and 2006. There were six men and five women with a mean age of 36 years (19 to 60). Initially, six patients had sustained a fracture of the distal tibia and fibula, one a midshaft fracture of the tibia and fibula, one a trimalleolar fracture, one a bimalleolar fracture, one a pilon fracture and one a severe soft-tissue injury without fracture. Treatment was by intramedullary nailing in four patients, fixation with a plate in two, external fixation in one, both external fixation and fixation with a plate in one, both intramedullary nailing and fixation with a plate in two and one was managed conservatively. The mean interval between injury and the development of the deformity was 3.5 months (2 to 7). Examination revealed a typical checkrein deformity, as when the ankle was dorsiflexed the interphalangeal joint of the hallux flexed sharply; on plantar flexion of the ankle, the interphalangeal joint extended completely. Five patients also had similar deformities on the second and third toes and in one the first and second toes were affected.

Lengthening by Z-plasty at the midfoot. A longitudinal incision was made along the upper border of abductor hallucis muscle of the midfoot. The tendons of FHL and flexor digitorum longus (FDL) were identified. If there were deformities on the second and third toes pre-operatively the tendinous interconnections between the FHL and the FDL were divided. This improved the deformities in those toes without further procewas performed by Z-plasty to allow full extension of the interphalangeal and metatarsophalangeal joint with the ankle in a neutral position. After operation a short removable splint was applied for two weeks to protect the procedure but movement of the ankle and toe was allowed immediately. dures. Lengthening of the tendon of FHL 
Table I. Details of 11 patients with checkrein deformity

\begin{tabular}{|c|c|c|c|c|c|c|c|c|c|c|c|}
\hline \multirow[b]{2}{*}{ Patient } & \multirow[b]{2}{*}{ Gender } & \multirow[b]{2}{*}{$\begin{array}{l}\text { Age } \\
\text { (yrs) }\end{array}$} & \multirow[b]{2}{*}{ Fracture } & \multirow[b]{2}{*}{$\begin{array}{l}\text { Mechanism } \\
\text { of injury }\end{array}$} & \multicolumn{7}{|l|}{ Treatment } \\
\hline & & & & & $\begin{array}{l}\text { Fracture } \\
\text { management }\end{array}$ & $\begin{array}{l}\text { Onset of } \\
\text { deformity } \\
\text { after injury } \\
\text { (mths) }\end{array}$ & $\begin{array}{l}\text { Affected } \\
\text { toes }\end{array}$ & $\begin{array}{l}\text { Follow-up } \\
\text { (mths) }\end{array}$ & $\begin{array}{l}\text { Lengthening } \\
\text { site }\end{array}$ & Recurrence & $\begin{array}{l}\text { Secondary } \\
\text { operation }\end{array}$ \\
\hline 1 & $M$ & 23 & $\begin{array}{l}\text { Distal fracture of } \\
\text { tibia and } \\
\text { fibula }\end{array}$ & $\begin{array}{l}\text { Sporting } \\
\text { injury }\end{array}$ & $\begin{array}{l}\text { Intramedullary } \\
\text { nailing }\end{array}$ & 2 & 1 & 40 & Above ankle & None & None \\
\hline 2 & $\mathrm{M}$ & 49 & $\begin{array}{l}\text { Midshaft } \\
\text { fracture of tibia and } \\
\text { fibula }\end{array}$ & $\begin{array}{l}\text { Car traffic } \\
\text { laccident }\end{array}$ & $\begin{array}{l}\text { Intramedullary } \\
\text { nailing }\end{array}$ & 3 & 1 & 25 & Above ankle & None & None \\
\hline 3 & $\mathrm{~F}$ & 37 & $\begin{array}{l}\text { Distal fracture of } \\
\text { tibia and } \\
\text { fibula }\end{array}$ & Fall & $\begin{array}{l}\text { External } \\
\text { fixation only }\end{array}$ & 3 & $1,2,3$ & 22 & Above ankle & $\begin{array}{l}\text { Partial } \\
\text { recurrence }\end{array}$ & None \\
\hline 4 & $\mathrm{~F}$ & 22 & $\begin{array}{l}\text { Open fracture of } \\
\text { distal tibia and } \\
\text { fibula }\end{array}$ & $\begin{array}{l}\text { Motorcycle } \\
\text { traffic accident }\end{array}$ & $\begin{array}{l}\text { Intramedullary } \\
\text { nailing }\end{array}$ & 2 & $1,2,3$ & 14 & Above ankle & $\begin{array}{l}\text { Partial } \\
\text { recurrence }\end{array}$ & None \\
\hline 5 & $\mathrm{~F}$ & 60 & $\begin{array}{l}\text { Open } \\
\text { segmental } \\
\text { fracture of distal } \\
\text { tibia and fibula }\end{array}$ & $\begin{array}{l}\text { Pedestrian } \\
\text { traffic accident }\end{array}$ & $\begin{array}{l}\text { Plate fixation + } \\
\text { intramedullary } \\
\text { nailing }\end{array}$ & 4 & 1,2 & 10 & Above ankle & $\begin{array}{l}\text { Complete } \\
\text { recurrence }^{\dagger}\end{array}$ & $\begin{array}{l}\mathrm{FHL}^{\ddagger} \\
\text { lengthening } \\
\text { (at midfoot) }\end{array}$ \\
\hline 6 & $M$ & 37 & $\begin{array}{l}\text { Pilon fracture of the } \\
\text { ankle }\end{array}$ & Snowboarding & $\begin{array}{l}\text { External } \\
\text { fixation }+ \\
\text { plate fixation }\end{array}$ & 3 & 1 & 8 & Midfoot & None & None \\
\hline 7 & $\mathrm{M}$ & 25 & $\begin{array}{l}\text { Trimalleolar } \\
\text { fracture of the } \\
\text { ankle }\end{array}$ & Direct blow & Plate fixation & 3 & $1,2,3$ & 10 & Midfoot & None & None \\
\hline 8 & $\mathrm{~F}$ & 45 & $\begin{array}{l}\text { Distal fracture of } \\
\text { the tibia and } \\
\text { fibula }\end{array}$ & $\begin{array}{l}\text { Motorcycle } \\
\text { traffic accident }\end{array}$ & $\begin{array}{l}\text { Plate fixation + } \\
\text { intramedullary } \\
\text { nailing }\end{array}$ & 7 & 1 & 24 & Midfoot & None & None \\
\hline 9 & $M$ & 48 & $\begin{array}{l}\text { Soft-tissue injury } \\
\text { without fracture }\end{array}$ & Jet skiing & $\begin{array}{l}\text { Conservative } \\
\text { treatment }\end{array}$ & 2 & $1,2,3$ & 20 & Midfoot & None & None \\
\hline 10 & $\mathrm{~F}$ & 31 & $\begin{array}{l}\text { Open } \\
\text { bimalleolar } \\
\text { fracture of the } \\
\text { ankle }\end{array}$ & $\begin{array}{l}\text { Pedestrian } \\
\text { traffic accident }\end{array}$ & Plate fixation & 6 & 1 & 43 & Midfoot & None & None \\
\hline 11 & $M$ & 19 & $\begin{array}{l}\text { Open fracture of } \\
\text { the distal tibia } \\
\text { and fibula }\end{array}$ & $\begin{array}{l}\text { Motorcycle } \\
\text { traffic } \\
\text { accident }\end{array}$ & $\begin{array}{l}\text { Intramedullary } \\
\text { nailing }\end{array}$ & 4 & $1,2,3$ & 8 & Midfoot & None & None \\
\hline
\end{tabular}

* partial recurrence, some improvement in symptoms but some residual deformities

$\dagger$ complete recurrence, a return to the same pre-operative status

$\ddagger \mathrm{FHL}$, flexor hallucis longus

Lengthening of the flexor hallucis longus tendon at the fracture site by Z-plasty with release of adhesions. A posteromedial approach was made to expose the tendon of FHL. Fibrous scar tissue was removed from the musculotendinous junction. After complete release of the adhesions the tendon was lengthened by Z-plasty. The post-operative management was the same as that following Z-plasty at the midfoot.

\section{Results}

The mean follow-up was 20.4 months ( 8 to 43 ). There was no recurrence of the deformity in the six patients who had lengthening by Z-plasty at the midfoot. Of the five patients who had a release of adhesions and lengthening by Z-plasty above the ankle, two showed partial and one a complete recurrence of the deformity. The two patients with partial recurrence showed gradual improvement and did not wish to have a further operation. The one with a complete recurrence had a further lengthening by Z-plasty on the medial side of the midfoot which resulted in complete resolution (Fig. 1).

In one of the patients who had a lengthening of FHL above the ankle the tendon was not adherent to the fracture site but the involved muscle seemed to be ischaemic, suggesting a subclinical compartment syndrome.

At the last follow-up, nine of the 11 patients had lost some flexion of the interphalangeal joint, but none had loss of function. The power of flexion at the metatarsophalangeal joint was normal and the ability to raise the heel was intact.

\section{Discussion}

The checkrein deformity is a dynamic flexion deformity of the tendon of FHL and usually occurs after fracture of the tibia. When the ankle is passively dorsiflexed the flexion deformity of the interphalangeal joint becomes more prominent. Because the FHL tendon has some interconnection to the tendons of FDL, deformities of the lesser toes are sometimes seen. 


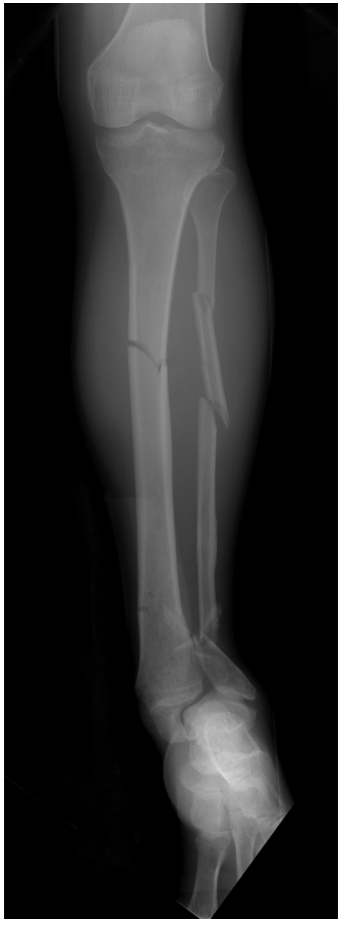

Fig. 1a

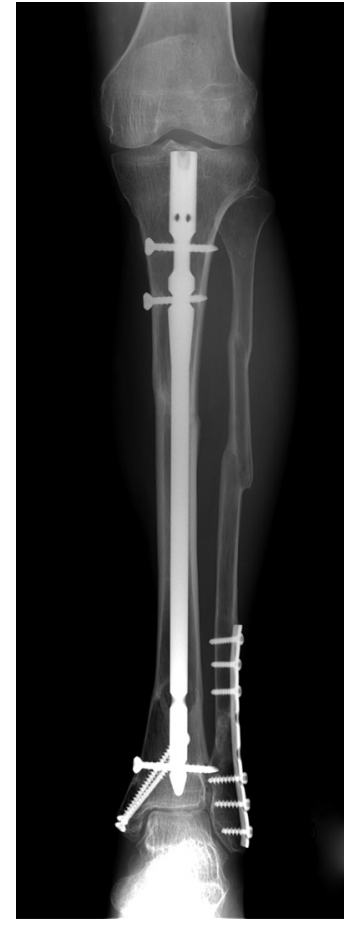

Fig. 1b

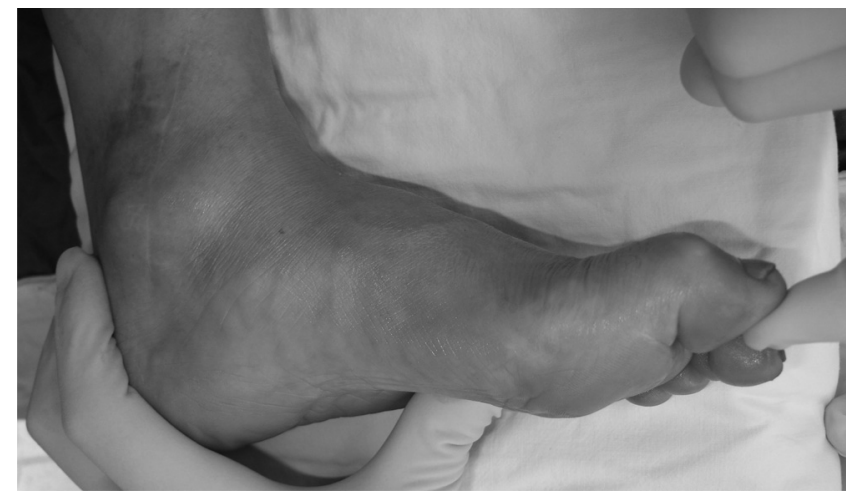

Fig. 1c

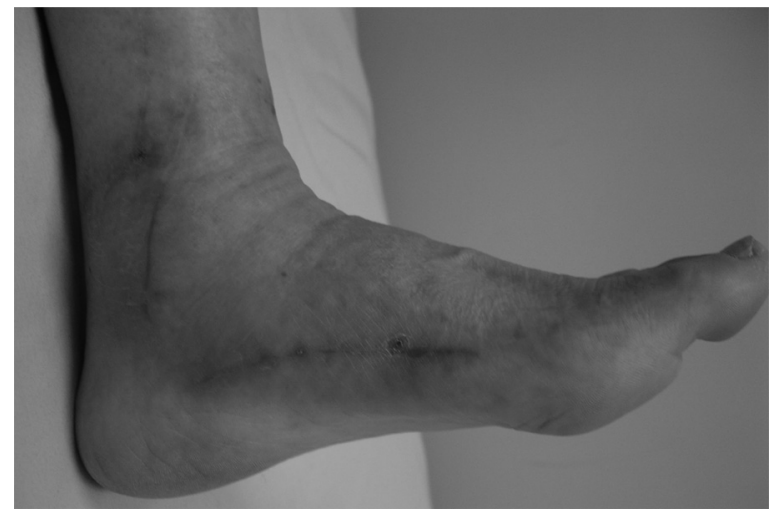

Fig. 1d

A 60-year-old woman with a checkrein deformity of the hallux, a) pre-operative radiograph showing a segmental fracture of the tibia and fibula, b) post-operative radiograph taken 22 months after the initial operation, c) the deformity recurred after release of adhesions and Z-plasty lengthening above the ankle at the fracture site. The checkrein deformity became more prominent when the ankle was passively dorsiflexed and d) correction after a second Z-plasty lengthening of the flexor hallucis longus tendon at the midfoot.

Since Clawson ${ }^{5}$ first described claw toes following fractures of the tibia in 1974, checkrein deformity has been observed in other circumstances. ${ }^{6}$ Carr $^{1}$ observed entrapment of the tendon of FHL after fractures of the calcaneum, and computerised tomography has demonstrated entrapment of the tendon in fracture fragments. Leitschuh et $\mathrm{al}^{3}$ noted a flexion deformity of the hallux secondary to entrapment of the tendon of FHL after a fracture of the fibula. The tendon was found to be adherent at the site of the healed fracture. ${ }^{3}$

The muscle bulk of the FHL is bigger than that of the FDL behind the distal tibia which may be one of the reasons that the FHL is involved more commonly.

Most of our patients sustained fractures of both the distal tibia and fibula. Fracture of the tibial shaft or the distal fibula may produce scarring of the FHL rather than more distant muscle tendon units. A typical checkrein deformity has been described after a concomitant fracture of the distal fibula., 3,7 Encouragment of early movement of the toes after injury is important especially with an associated fracture of the distal fibula.

The surgical management of checkrein deformity has included release of adhesions at the fracture site and lengthening of the FHL. ${ }^{4}$ Sanhudo and Lompa ${ }^{7}$ suggested that lengthening of the tendon at the level of the midfoot is better than at a site posterior to the ankle. Feeney et $\mathrm{al}^{2}$ stated that lengthening of the FHL alone is sufficient to treat concomitant checkrein deformity of the lesser toes because there are tendinous interconnections between the FHL and the FDL.

We prefer to carry out lengthening of the tendon of FHL by Z-plasty in the foot in preference to above the ankle as the surgical fields are relatively simple and are free of scar tissue. There is, therefore, less chance of recurrence of adhesions. In addition, separate lengthening of the FHL and FDL is sometimes needed, and operation in the foot allows division of the tendon interconnection between FHL and FDL. Meanwhile, operation at the site of fracture requires a large incision with dissection of neurovascular structures. 
In summary, we found that lengthening of the tendon of FHL by Z-plasty in the foot provided relatively good clinical results and appeared to offer the best surgical treatment for checkrein deformity.

No benefits in any form have been received or will be received from a commercial party related directly or indirectly to the subject of this article.

\section{References}

1. Carr JB. Complications of calcaneus fractures entrapment of the flexor hallucis longus: report of two cases. J Orthop Trauma 1990;4:166-8.

2. Feeney MS, Williams RL, Stephens MM. Selective lengthening of the proximal flexor tendon in the management of acquired claw toes. J Bone Joint Surg $[\mathrm{Br}]$ 2001:83-B:335-8.
3. Leitschuh PH, Zimmerman JP, Uhorchak JM, Arciero RA, Bowser L. Hallux flexion deformity secondary to entrapment of the flexor hallucis longus tendon after fibular fracture. Foot Ankle Int 1995;16:232-5

4. Carranza-Bencano A, Gómez-Arroyo JA, Fernández-Torres JJ. Hallux flexus deformity due to entrapment of the flexor hallucis longus tendon after an open fracture of the tibia and fibula. Foot Ankle Surg 2000;6:133-5.

5. Clawson DK. Claw toes following tibial fracture. Clin Orthop 1974;103:47-8.

6. Rosenberg GA, Sferra JJ. Checkrein deformity: an unusual complication associated with a closed Salter-Harris Type II ankle fracture: a case report. Foot Ankle Int 1999;20:591-4.

7. Sanhudo JA, Lompa PA. Checkrein deformity: flexor hallucis tethering: two case reports. Foot Ankle Int 2002;23:799-800. 